\title{
A Brief Report of Pingdi Landslide (23 July 2019) in Guizhou Province, China
}

\author{
Tao Yan ${ }^{1}$, Shui-Long Shen ${ }^{2, *}{ }^{\mathbb{C}}$, An-Nan Zhou ${ }^{3}$ and Jun Chen ${ }^{1}$ \\ 1 State Key Laboratory of Ocean Engineering, Department of Civil Engineering, School of Naval Architecture, \\ Ocean, and Civil Engineering, Shanghai Jiao Tong University, Shanghai 200240, China \\ 2 Key Laboratory of Intelligent Manufacturing Technology (Shantou University), Ministry of Education, and \\ Department of Civil and Environmental Engineering, College of Engineering, Shantou University, Shantou, \\ Guangdong 515063, China \\ 3 Civil and Infrastructure Engineering Discipline, School of Engineering, Royal Melbourne Institute of \\ Technology (RMIT), Melbourne, Victoria 3001, Australia \\ * Correspondence: shensl@stu.edu.cn; Tel.: +86-21-3420-4301
}

Received: 30 July 2019; Accepted: 22 August 2019; Published: 24 August 2019

check for updates

\begin{abstract}
This short communication reports on a large landslide with a movement of 2 million $\mathrm{m}^{3}$ of soil and rock that occurred on 23 July, 2019 in the village of Pingdi, located in the county of Shuicheng, Guizhou Province, China. This landslide resulted in 42 deaths and 9 missing people. This report describes the preliminary investigation, rescue effort, and possible cause. The total rainfall in the 6 days prior to the landslide was $189.1 \mathrm{~mm}$, which may be held responsible as the major cause. Some recommendations are proposed to reduce human casualties and property losses.
\end{abstract}

Keywords: landslide; pingdi; rainfall; recommendations

\section{Introduction}

As a result of global climate change and alteration of the natural environment by human engineering activities, the frequent occurrence of geological disasters has posed an enormous threat to both property and safety of humans [1-3]. According to a report, 130 million people were affected by natural disasters in 2008. Natural disasters also resulted in 589 deaths and 46 missing people and totalled 264.46 billion Ren Min Bi (RMB) of direct economic losses [4]. Landslides, which are major geological disaster, have frequently occurred in recent years, posing a significant risk to property and safety of people [5-7]. According to the National Bureau of Statistics (NBS), 5524 landslides occurred nationwide in 2017 [8]. Therefore, the early warning and prevention of landslides are of tremendous importance and are urgently required.

In recent years, with the development of Remote Sensing (RS) and the Geographic Information System (GIS), spatial information processing technology has been widely used in the evaluation of landslide vulnerability [9-15]. The combination of spatial information processing software and statistical analysis tools significantly improves the efficiency of data acquisition, processing, and analysis, and promotes the application of the state-of-the-art methods and models in evaluating landslide risks. In addition, a satellite image receiving system has been used to cover the entire country to obtain the information about geological disasters and a weather radar can be used to predict the possible rainfall in advance to warn humans against geological disasters [16]. Despite the efforts made by governments and researchers, it is still an enormous challenge to predict and/or prevent landslides. Recently, a large landslide (23 July, 2019) occurred in the village of Pingdi, Shuicheng County, Guizhou Province. This article presents a preliminary investigation of the Pingdi landslide. In this article, the landslide and rescue measures are presented, the main causes of the landslide are discussed, and recommendations are provided to reduce human casualties and property losses. 


\section{Methodology}

\subsection{Preliminary Investigation}

A large landslide occurred in Pingdi village at approximately 9:20 p.m. on 23 July (see Figure 1). Pingdi village, with a population of approximately 6000, is located in the west of Guiyang, the capital of Guizhou Province. In this landslide, approximately 2 million $\mathrm{m}^{3}$ of soil and rock moved down the mountain foot from a height of $500 \mathrm{~m}$ (the vertical distance between the highest point and toe of the landslide). The landslide destroyed 27 houses, of which 21 were buried and some were dislodged a distance of approximately $100 \mathrm{~m}$. Figure $2 \mathrm{a}$, b show the houses in a three-dimensional (3D) view from Google Earth before the landslide and a photograph captured after the landslide, respectively. The altitude of the landslide was located at a longitude of $104^{\circ} 40^{\prime} \mathrm{E}$ and latitude of $26^{\circ} 15^{\prime} \mathrm{N}$, and its duration was estimated to be approximately $60 \mathrm{~s}$.
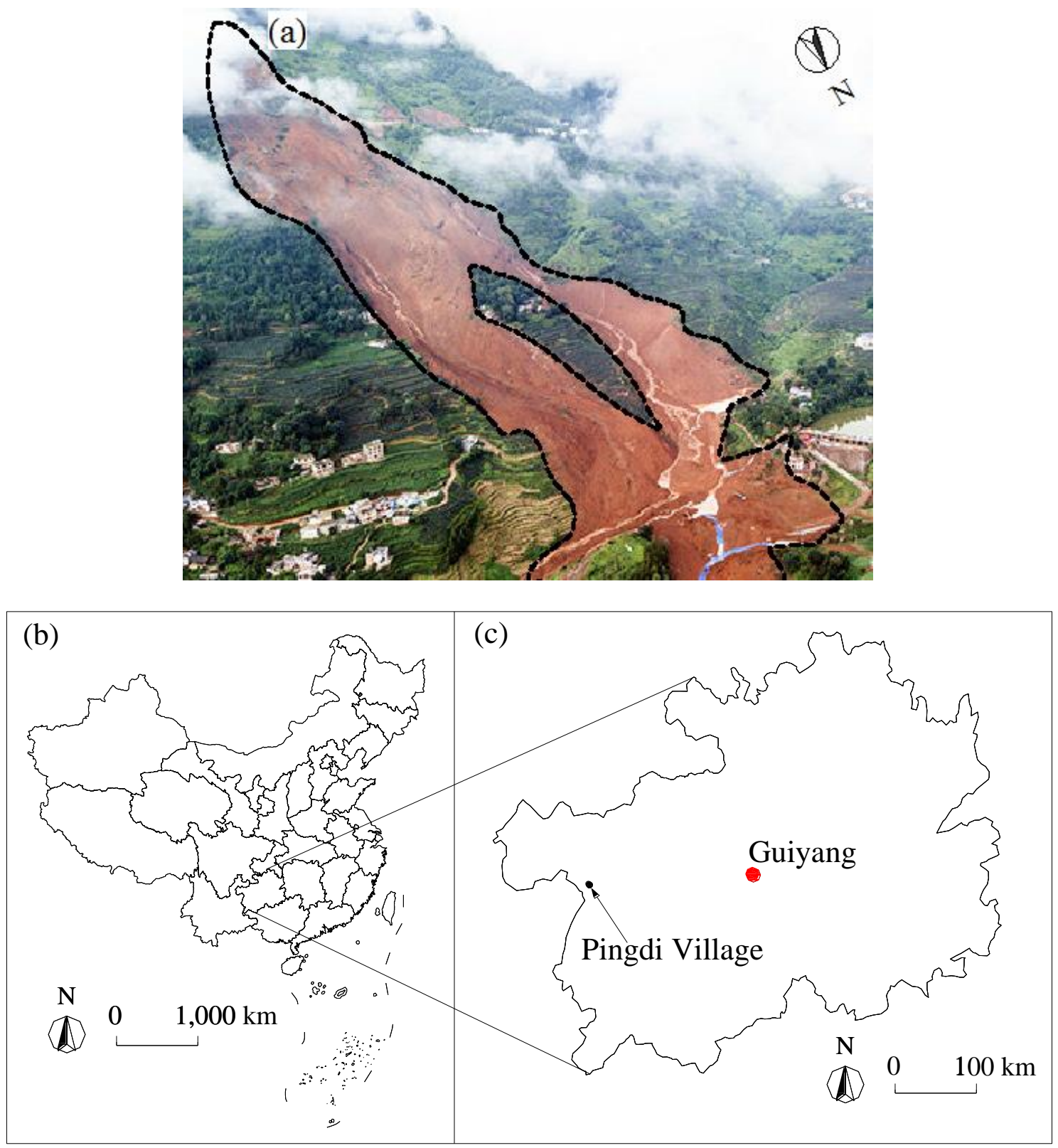

Figure 1. (a) Pingdi village after the landslide (Source: http://baijiahao.baidu.com/s?id= 1639927165371855884 ) (b) location of Guizhou, and (c) Location of Pingdi village. 


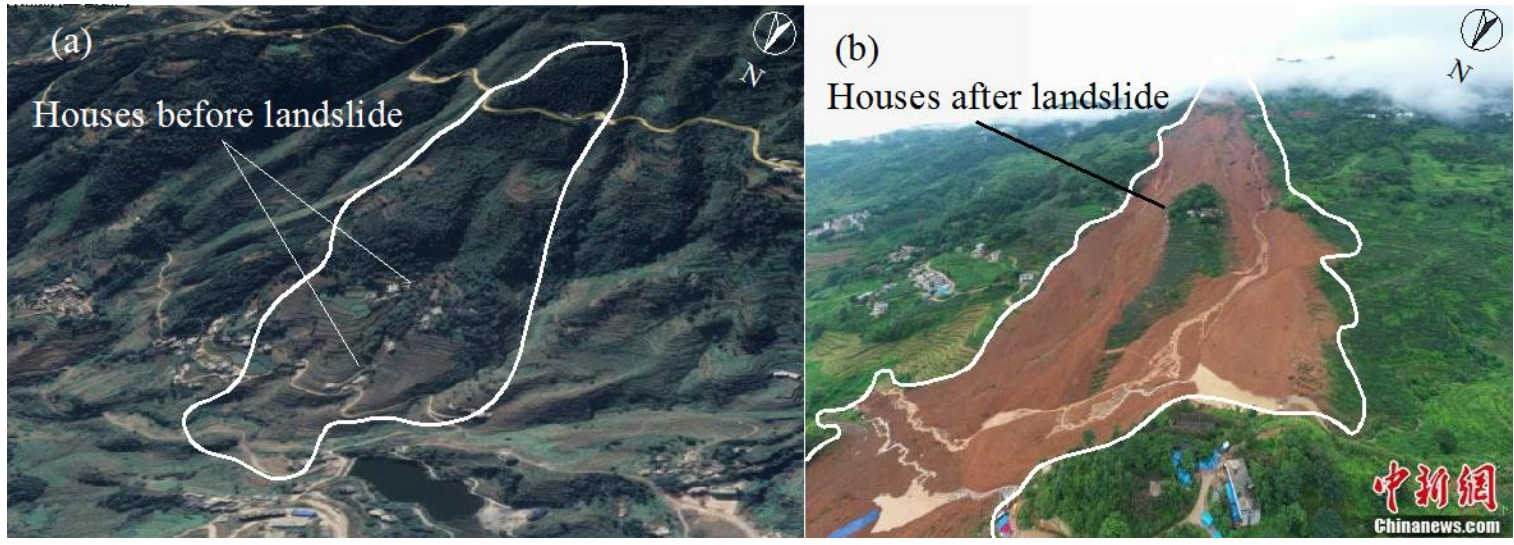

Figure 2. (a) Three-dimensional (3D) View from Google Earth before the landslide (b) Photo captured after the landslide (Source: http://gz.people.com.cn/n2/2019/0724/c194849-33174976-7.html).

Figure 3 presents an overview of the site after the landslide. The vertical distance and sliding trajectory along the sliding surface of the landslide were approximately $500 \mathrm{~m}$ and $1400 \mathrm{~m}$, respectively. The average slope of the landslide was $18^{\circ}$, and its average thickness was $5 \mathrm{~m}$. In addition, barrier lakes were formed by the landslide, which could cause some secondary hazards and exacerbate the consequences of the landslide (see Figure 4). As of 23:00 on July 28, the landslide had resulted in 42 deaths and 9 missing persons.

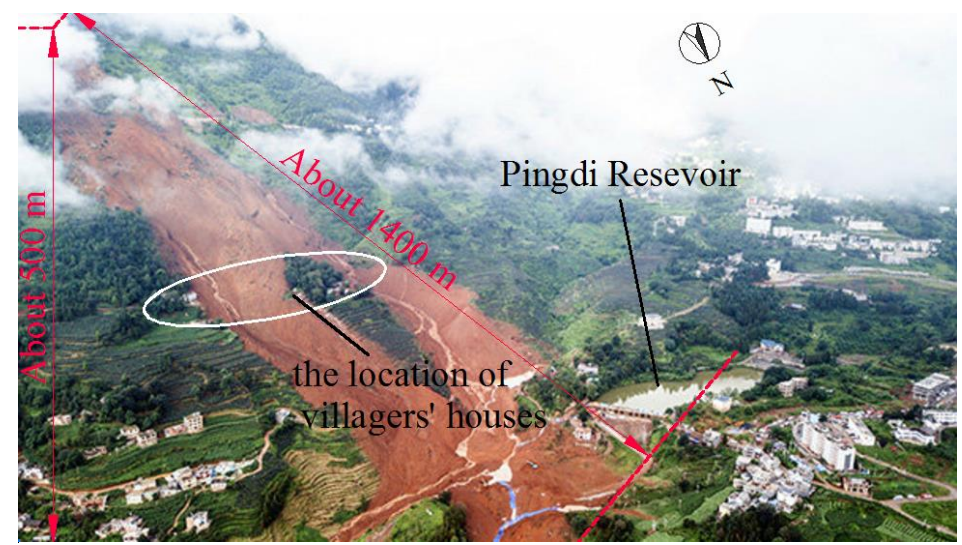

Figure 3. Overview of the landslide (Source: http://baijiahao.baidu.com/s?id=1639927165371855884).

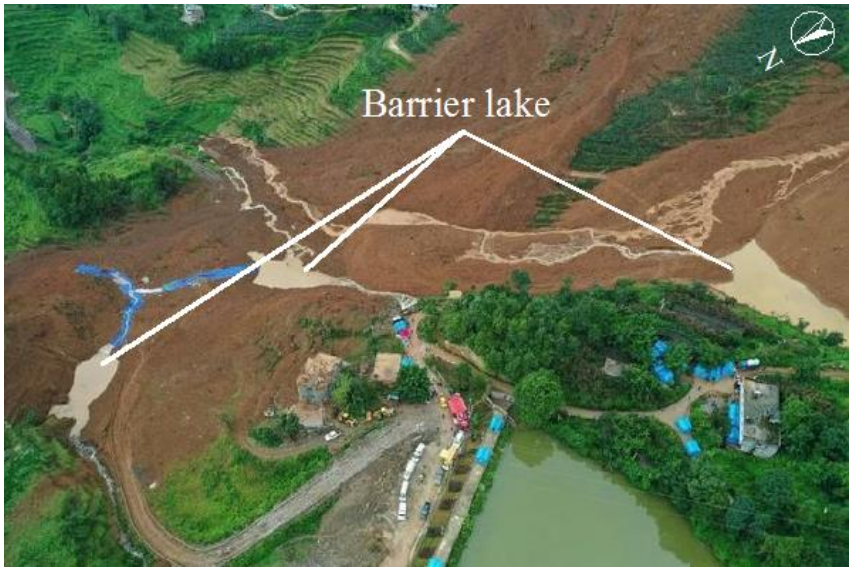

Figure 4. Barrier lakes formed after the landslide (Source: http://www.chinanews.com/tp/hd2011/2019/ 07-24/893609.shtml). 
Figure 5 presents three points in the landslide where 21 houses were buried. Continuous rainfall caused another landslide occurrence in point B on July 25, whereas point $C$ received the soil and rock sliding from points $\mathrm{A}$ and $\mathrm{B}$. It was estimated that point $\mathrm{C}$ had a high risk of debris flow. Therefore, the rescue at point $C$ was suspended on July 25.

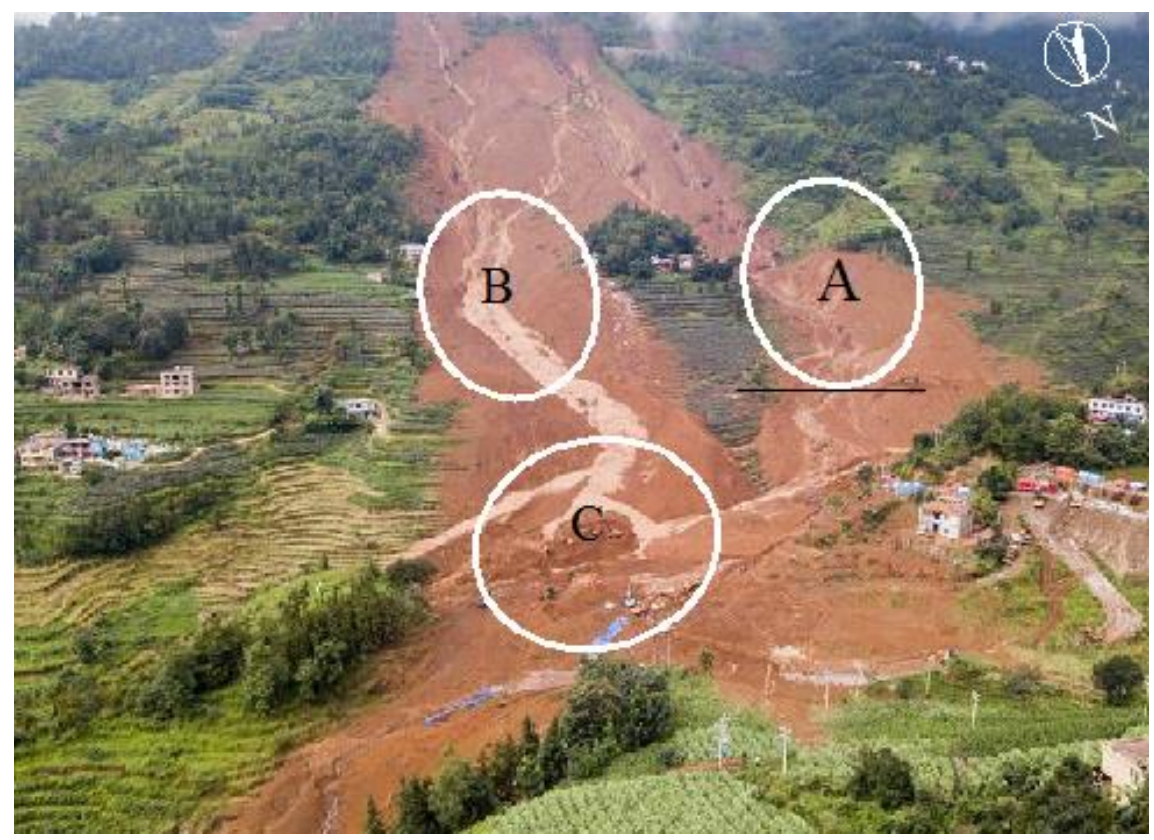

Figure 5. Three points A, B, and C of the rescue areas (Source: http://gz.people.com.cn/n2/2019/0724/ c194849-33174976-2.html).

\subsection{Data Source}

To report and analyze this landslide, the photos captured from the site of the landslide were collected from websites, and the weather data records were collected from the National Meteorological Information Center of China (NMC, https://data.cma.cn/). The latter includes the annual average monthly rainfall, highest temperature (H-temperature), and lowest temperature (L-temperature) in Pingdi village. In addition, the recent rainfall data records of Pingdi village were collected from the Meteorological Bureau of Guizhou province.

\section{Rescue Effort}

More than 1500 people were on the site to rescue victims immediately after the landslide, and more rescue teams arrived in the following days including firefighters, police, mine rescue professionals, the Guiyang Tunnel Rescue Team, the Blue Sky Rescue Team, and other civilian rescue teams. On the day of the landslide, the Department of Emergency Management of Guizhou Province immediately dispatched 400 tents, 400 quilts, and 1000 raincoats, as well as lighting equipment, drinking water and food. Other rescue supplies began arriving in the following days. In addition, numerous vehicles and helicopters were involved in the rescue activities. Rescue teams used helicopters to transport the injured (including two children) to the Guizhou provincial hospital for treatment. As shown in Figure $6 \mathrm{a}$, firefighters cleared the barrier at the site of the landslide and drained the barrier lake (see Figure 4) to prevent secondary disasters. However, another landslide occurred at point B (see Figure 5) on July 25, and a debris flow occurred at point C. Rescue operators had evacuated the people at these two points prior to the second landslide, resulting in no further casualties. The rescue efforts are currently continuing, with 11 people rescued. Figure $6 b, c$ depict the rescue professionals saving people from buried houses. In addition, the government urgently allocated 30 million RMB for disaster relief, and a further 12 million RMB for investing in the rescue activities from the Guizhou Province. 


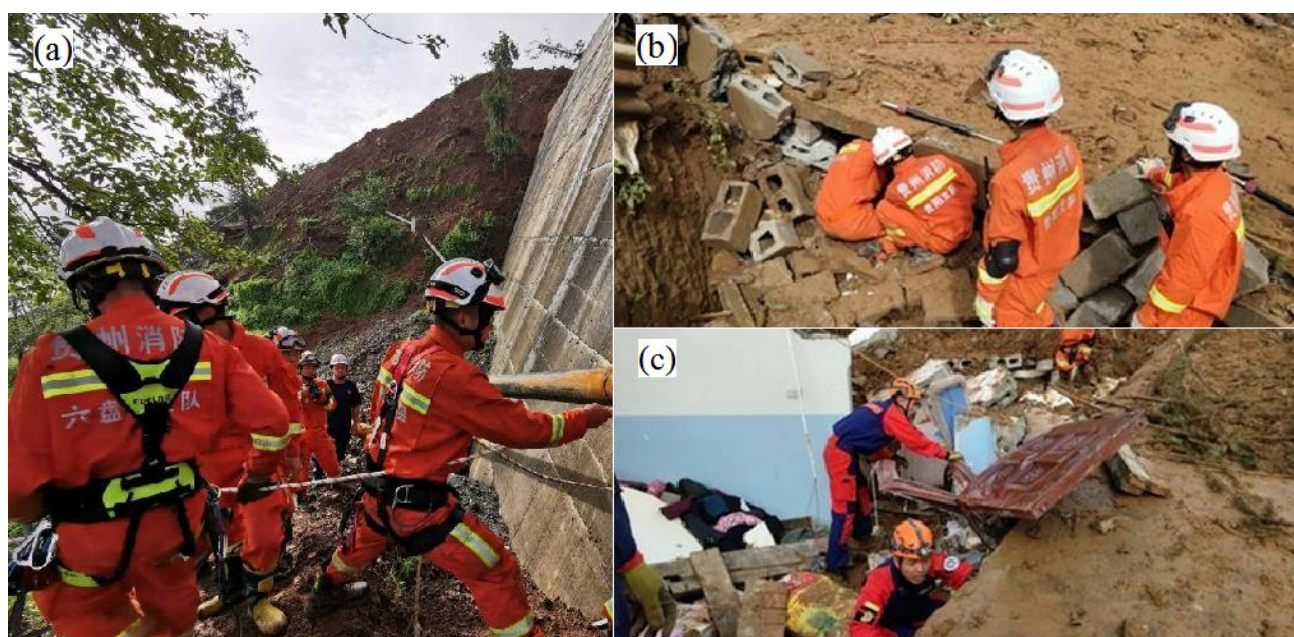

Figure 6. Rescue activities (a) Firefighters clearing a barrier (Source: http://www.chinanews.com) (b) Firefighters rescuing people from buried houses, and (c) Rescue team rescuing people from buried houses (Source: http://www.360kuai.com/ (b,c))

\section{Analysis and Discussions}

\subsection{Rainfall}

Shuicheng, located in the west of Guizhou Province, is a mountainous area bordering the Yunnan Province. The average annual rainfall in Shuicheng is $1347.9 \mathrm{~mm}$, particularly in June and July, when it is 305.3 and $265.5 \mathrm{~mm}$, respectively (see Figure 7a). Therefore, a landslide probably occurs in June and July. The cumulative rainfall has reached $288.9 \mathrm{~mm}$ since this July, and heavy rainfall was concentrated in the first 6 days before the landslide. The rainfall was $49 \mathrm{~mm}$ on July $19,37.1 \mathrm{~mm}$ on July 20, and $98 \mathrm{~mm}$ on July 23. The total rainfall in the 6 days before the landslide was $189.1 \mathrm{~mm}$ (see Figure $7 \mathrm{~b}$ ), which may be blamed as the major cause for this landslide. By authors' opinion, the landslide may be attributed to continuous heavy rainfall. Empirical evidence [17] strengthen this hypothesis as the rainfall peak of 23 July ( $98 \mathrm{~mm}$ in $24 \mathrm{~h}$ ) is higher than almost all the rainfall thresholds for landslide initiation reported in a recent review at the global scale. The surface drainage was obstructed at some points where a large amount of stormwater was collected locally, resulting in sever water infiltrations $[3,18]$. The unit weight of soil increased significantly when it was saturated with water, resulting in an increase in the sliding force. Concurrently, the pore water pressure increased, significantly reducing the soil shear strength resulting in a reduction in the sliding resistance $[19,20]$. Finally, a catastrophic landslide occurred when the sliding force exceeded the sliding resistance.
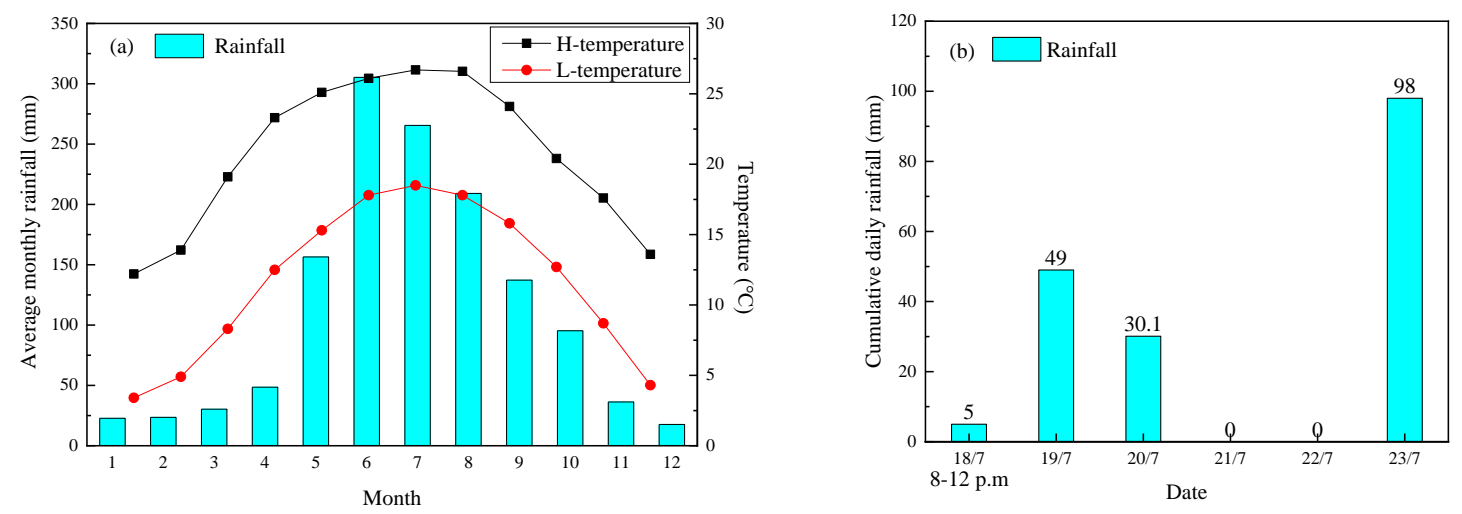

Figure 7. (a) Average monthly rainfall, highest temperature (H-temperature), and lowest temperature (L-temperature) in Pingdi village and (b) the rainfall prior to the landslide. 


\subsection{Recommendations}

A landslide is considered as a most serious natural disaster, which leads to human casualties and enormous property losses. Numerous measures are used to monitor the occurrence of geological disasters. Instrument monitoring, manual monitoring, station observation and automatic remote sensing methods are commonly used in landslide monitoring [21]. According to the Ministry of Emergency Management of China (MEM), numerous locations remain that may be blind spots for the early warning of geological disasters [22]. Moreover, in the Emergency Response Law of the People's Republic of China, an early warning of a geological disaster can only be sent to the county level [23]. However, there are numerous villages (particularly some in the mountainous area in the west of China) with poor communication. Therefore, the hazard management department of the county may be unable to inform every village in it [22]. In addition, in the disaster prevention of China, in geological disaster emergency treatment, villagers are not involved in the early warning and evacuation of geological disasters (see Figure 8).

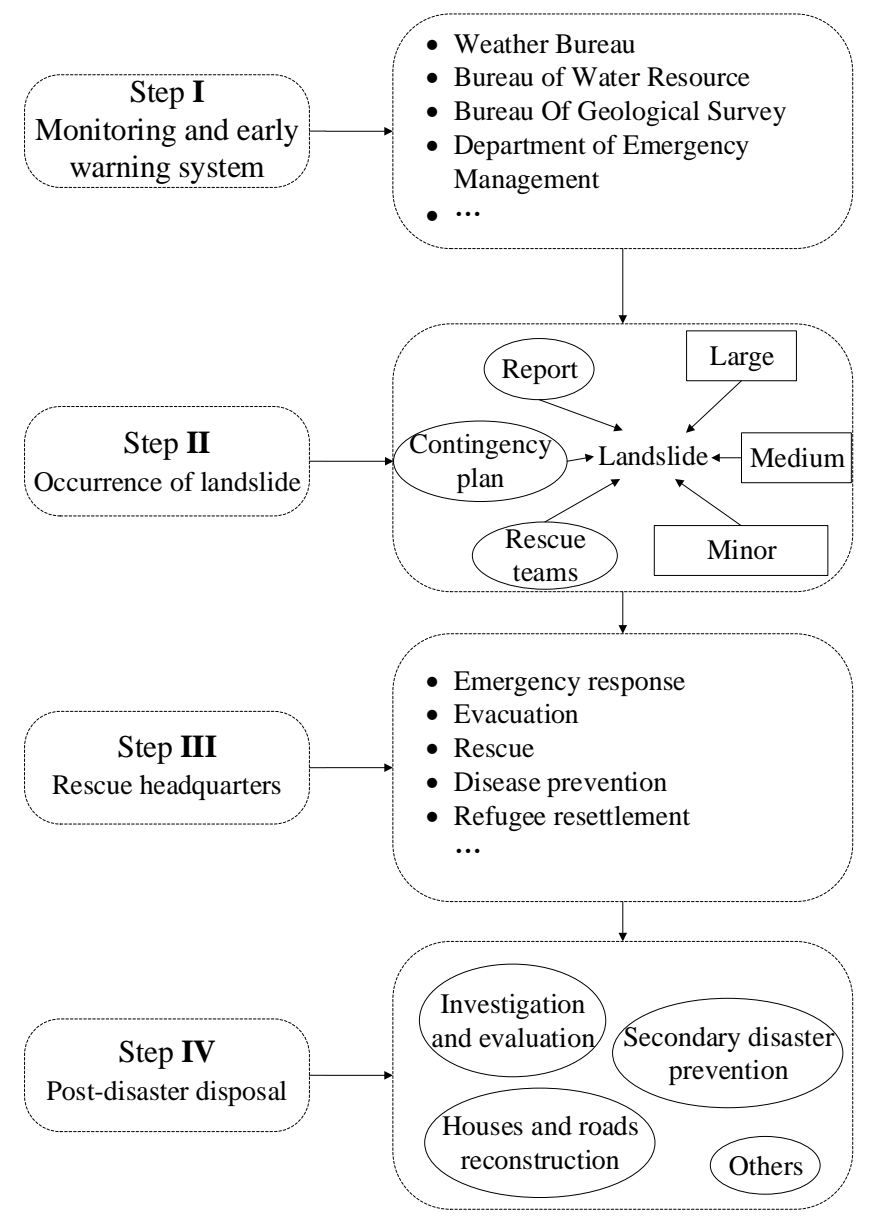

Figure 8. Flow chart of geological disaster emergency treatment in China.

Figure 9 exhibits the disaster preparedness system in Japan. The laws and regulations may provide guidance for disaster prevention. Rescue teams can arrive at a site immediately in a geology disaster with disaster prevention system [24]. In addition, more research on geological disaster prevention may provide more methods to achieve early warning. The most important method to prevent geology disaster is to increase the resilience of citizens; therefore, disaster prevention education and disaster prevention training are necessary [25].

According to the disaster preparedness system in Japan, some recommendations made should be adopted in the geology disasters in China. (1) The government should improve the existing emergency 
management legislation and disaster prevention system to strength the efficiency and effectiveness of an early warning system. (2) The most important point is that the villagers should reinforce the awareness and knowledge of self-prevention and enhance their ability to save themselves when encountering a natural disaster. In addition, villagers should practice disaster prevention training and evacuation rehearsal regularly.

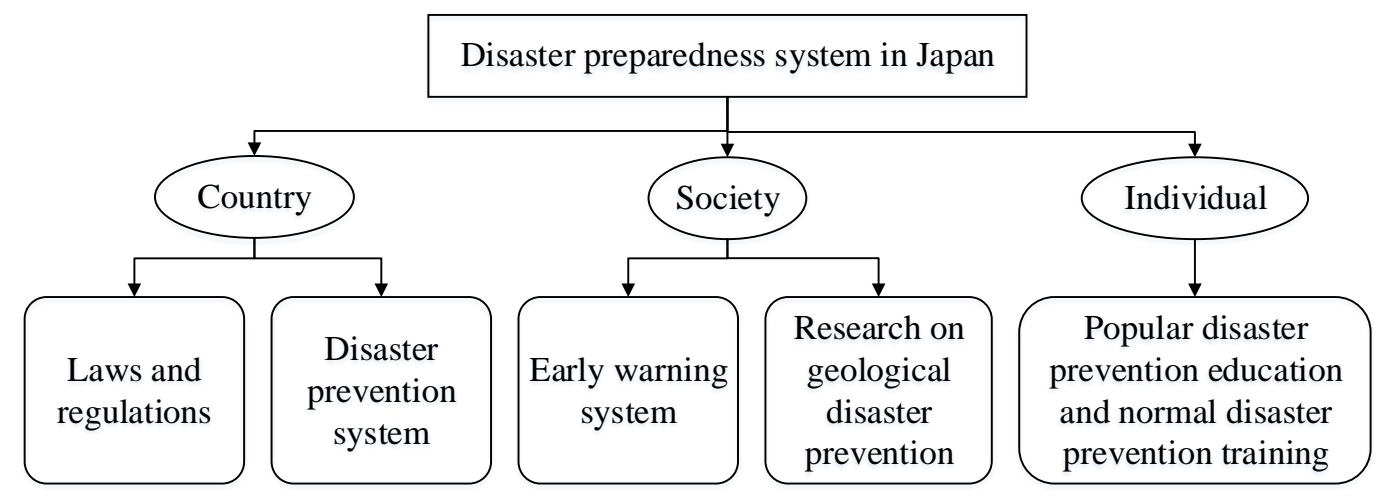

Figure 9. Disaster preparedness system in Japan.

At present, in view of the rapid development of the GIS technology, various quantitative or statistical methods have been proposed to predict landslide susceptibility [26]. For example, Shahabi et al. [27] compared the landslide susceptibility mapping models of logistic regression (LR), analytical hierarchy process (AHP) and frequency ratio (FR). Yalcin [28] compared the susceptibility maps produced by the analytical hierarchy process (AHP), statistical index (Wi), and weighting factor (Wf) methods. Based on the comparative study above mentioned, Yalcin [28] concluded that AHP method yielded a more realistic scenario of the actual distribution of the landslide susceptibility. Zhu et al. [29] applied the load-unload response ratio theory to establish a landslide prediction model. Yang et al. [30] applied a time series analysis and long short-term memory neural network to predict landslide displacement. The RS and permanent scatter interferometry synthetic aperture radar (PSInSAR) techniques are widely used to monitor the development of geohazards [31-37]. In addition, the most straightforward method to establish a territorial landslide early warning system is the definition of rainfall thresholds for landslide initiation $[17,38-40]$. The application of these model techniques could help in monitoring the occurrence of a landslide.

\section{Conclusions}

This short communication reports a large landslide that occurred on 23 July, 2019 in Guizhou Province, China. The following conclusions can be drawn based on the preliminary investigation and analysis.

1. A large landslide of approximately 2 million $\mathrm{m}^{3}$ of soil and rock occurred at Pingdi village, resulting in 42 deaths and 9 missing persons (as of July 28) being reported. In the preliminary investigation, the vertical distance between the highest point and toe of the landslide and sliding trajectory along the sliding surface of the landslide were approximately 500 and $1400 \mathrm{~m}$, respectively.

2. Rainfall was considered as the most important causing factor for this landslide. The continuous heavy rainfall significantly deteriorated the stormwater of the sliding interface. The shear stresses due to the deterioration of the sliding interface acted along the shear band, resulting in a reduced shear strength available at the shear band. This in turn caused a displacement of the soil and rock above, thereby triggering this massive landslide.

3. The government should strengthen the ability of warning and communication to inform villagers in time. In addition, the villagers should be educated regarding rescue during natural disasters 
and practice evacuation drills regularly. In addition, more risk prediction methods should be applied to prevent geological disasters.

Author Contributions: This paper represents a result of collaborative teamwork. S.-L.S. developed the concept; T.Y. drafted the manuscript; A.-N.Z. and J.C. provided constructive suggestions and revised for the manuscript. The four authors contributed equally to this work.

Funding: This research was funded by the Research Funding of Shantou University for New Faculty (Grant No. NTF19024-2019) and the Innovative Research Funding of the Science and Technology Commission of Shanghai Municipality (Grant No. 18DZ1201102).

Acknowledgments: The authors would like to express their sincere appreciation to the anonymous reviewers and editors, whose constructive suggestions helped the authors to rethink and rework the manuscript to improve the quality greatly.

Conflicts of Interest: The authors declare no conflict of interest.

\section{References}

1. Xu, Y.S.; Shen, S.L.; Lai, Y.; Zhou, A.N. Design of sponge city: Lessons learnt from an ancient drainage system in Ganzhou, China. J. Hydrol. 2018, 563, 900-908. [CrossRef]

2. Xu, Y.S.; Yan, X.X.; Shen, S.L.; Zhou, A.N. Experimental investigation on the blocking of groundwater seepage from a waterproof curtain during pumped dewatering in an excavation. Hydrogeol. J 2019, 1-14. [CrossRef]

3. Lyu, H.M.; Wang, G.F.; Cheng, W.C.; Shen, S.L. Tornado hazards on June 23rd in Jiangsu Province, China: preliminary investigation and analysis. Nat. Hazards 2017, 85, 597-604. [CrossRef]

4. Ministry of Emergency Management of the People's Republic of China (MEM). Ministry of Emergency Management of the People's Republic of China and the National Disaster Reduction Commission have released basic information on natural disasters in 2018. Available online: http://www.mem.gov.cn/xw/zhsgxx/ 201901/t20190108_242580.shtml (accessed on 8 January 2019). (In Chinese)

5. Bezak, N.; Auflič, M.J.; Mikoš, M. Application of hydrological modelling for temporal prediction of rainfall-induced shallow landslides. Landslides 2019, 16, 1273-1283. [CrossRef]

6. Meng, W.; Xu, Y.; Cheng, W.C.; Arulrajah, A. Landslide event on 24 June in Sichuan Province, China: Preliminary investigation and analysis. Geosciences 2018, 8, 39. [CrossRef]

7. Bogaard, T.; Greco, R. Invited perspectives: Hydrological perspectives on precipitation intensity-duration thresholds for landslide initiation: Proposing hydro-meteorological thresholds. Nat. Hazards Earth Syst. Sci. 2018, 18, 31-39. [CrossRef]

8. National Bureau of Statistics (NBS). China statistical yearbook 2018; National Bureau of Statistics: Beijing, China, 2018. Available online: http://www.stats.gov.cn/tjsj/ndsj/2018/indexch.htm (accessed on 22 June 2019). (In Chinese)

9. Cong, W.G.; Pan, M.; Li, T.F.; Wu, Z.X.; Lü, G.X.; Lo, G.X. Key research on landslide and debris flow hazard zonation based on GIS. Dixue Qianyuan/ Earth Sci. Front. 2006, 13, 185-190.

10. Liang, S.; Yang, X. Landslide hazard assessment based on GIS: A case study of a hydropower station area in China. In Proceedings of the 2008 International Workshop on Education Technology and Training \& 2008 International Workshop on Geoscience and Remote Sensing, Shanghai, China, 21-22 December 2008; pp. 155-158.

11. Lyu, H.M.; Sun, W.J.; Shen, S.L.; Arulrajah, A. Flood risk assessment in metro systems of mega-cities using a GIS-based modeling approach. Sci. Total. Environ. 2018, 626, 1012-1025. [CrossRef]

12. Lyu, H.-M.; Shen, J.S.; Arulrajah, A. assessment of geohazards and preventative countermeasures using ahp incorporated with GIS in Lanzhou, China. Sustainability 2018, 10, 304. [CrossRef]

13. Peng, J.; Peng, F.-L. A GIS-based evaluation method of underground space resources for urban spatial planning: Part 1 methodology. Tunn. Undergr. Space Technol. 2018, 74, 82-95. [CrossRef]

14. Qiao, Y.K.; Peng, F.L.; Wang, Y. Monetary valuation of urban underground space: A critical issue for the decision-making of urban underground space development. Land Use Policy 2017, 69, 12-24. [CrossRef]

15. Qiao, Y.K.; Peng, F.L.; Sabri, S.; Rajabifard, A. low carbon effects of urban underground space. Sustain. Cities Soc. 2019, 45, 451-459. [CrossRef]

16. Caracciolo, D.; Arnone, E.; Conti, F.L.; Noto, L.V. Exploiting historical rainfall and landslide data in a spatial database for the derivation of critical rainfall thresholds. Environ. Earth Sci. 2017, 76, 222. [CrossRef] 
17. Segoni, S.; Piciullo, L.; Gariano, S.L. A review of the recent literature on rainfall thresholds for landslide occurrence. Landslides 2018, 15, 1483-1501. [CrossRef]

18. Liu, X.X.; Shen, S.L.; Zhou, A.N.; Xu, Y.S. Evaluation of foam conditioning effect on groundwater inflow at tunnel cutting face. Int. J. Numer. Anal. Methods Geomech. 2019, 43, 463-481. [CrossRef]

19. Wang, X.W.; Yang, T.L.; Xu, Y.S.; Shen, S.L. Evaluation of optimized depth of waterproof curtain to mitigate negative impacts during dewatering. J. Hydrol. 2019, 577, 123969. [CrossRef]

20. Wu, Y.X.; Lyu, H.M.; Han, J.; Shen, S.L. Dewatering-induced building settlement around a deep excavation in soft deposit in Tianjin, China. J. Geotech. Geoenviron. Eng. 2019, 145, 05019003. [CrossRef]

21. She, X.N. Comprehensive comments on the present situation of monitoring collapse and landslide. J. Railw. Eng. Soc. 2007, 5, 6-11. (In Chinese)

22. Ministry of Emergency Management of the People's Republic of China (MEM). Opinions of the General Office of the State Council on Strengthening Meteorological Disaster Monitoring, Early Warning and Information Release. Available online: http://www.mem.gov.cn/fw/flfgbz/fg/gwywj/201107/t20110714_232750.shtml (accessed on 14 July 2011). (In Chinese)

23. Ministry of Emergency Management of the People's Republic of China (MEM). Emergency Response Law of the People's Republic of China. Available online: http://www.mem.gov.cn/fw/flfgbz/fl/200709/t20070924_ 232540.shtml (accessed on 24 September 2007). (In Chinese)

24. Lin, C.N. Earthquake Disaster Prevention for Life; Iwanami Shoten: Tokyo, Japan, 2003. (In Japanese)

25. Wu, L.H.; Bao, S. Construction of Emergency Management System of Earthquake Disasters in Japan. J. Inst. Disaster Prev. 2017, 19, 54-63. (In Chinese)

26. Wang, L.-J.; Guo, M.; Sawada, K.; Lin, J.; Zhang, J. Landslide susceptibility mapping in Mizunami City, Japan: A comparison between logistic regression, bivariate statistical analysis and multivariate adaptive regression spline models. Catena 2015, 135, 271-282. [CrossRef]

27. Shahabi, H.; Khezri, S.; Bin Ahmad, B.; Hashim, M. Landslide susceptibility mapping at central Zab basin, Iran: A comparison between analytical hierarchy process, frequency ratio and logistic regression models. Catena 2014, 115, 55-70. [CrossRef]

28. Yalcin, A.; Yalçın, A. GIS-based landslide susceptibility mapping using analytical hierarchy process and bivariate statistics in Ardesen (Turkey): Comparisons of results and confirmations. Catena 2008, 72, 1-12. [CrossRef]

29. Zhu, Z.; Wang, X.C.; Zhang, P.; He, M.C. A landslide prediction model based on load-unload response ratio theory and its application. DYNA-ingeniería e industria 2019, 94, 304-312. [CrossRef]

30. Yang, B.; Yin, K.; Lacasse, S.; Liu, Z. Time series analysis and long short-term memory neural network to predict landslide displacement. Landslides 2019, 16, 677-694. [CrossRef]

31. Anderson, S.A. Remote Sensing Applications for Landslides, Slopes and Embankments. Geo-Congress 2013, III, 2204-2223.

32. Czikhardt, R.; Papco, J.; Bakon, M.; Liscak, P.; Ondrejka, P.; Zlocha, M. Ground stability monitoring of undermined and landslide prone areas by means of sentinel-1 multi-temporal InSAR, case study from Slovakia. Geosciences 2017, 7, 87. [CrossRef]

33. Liu, J.; Mason, P.J.; Bryant, E.C. Regional assessment of geohazard recovery eight years after the Mw 7.9 Wenchuan earthquake: a remote-sensing investigation of the Beichuan region. Int. J. Remote Sens 2018, 39, 1671-1695. [CrossRef]

34. Lyu, H.M.; Sun, W.J.; Shen, S.L.; Zhou, A.N. Risk assessment using a new consulting process in fuzzy AHP. J. Constr. Eng. Manag. 2019. In press. [CrossRef]

35. Lyu, H.M.; Shen, S.L.; Zhou, A.N.; Zhou, W.H. Flood risk assessment of metro systems in a subsiding environment using the interval FAHP-FCA approach. Sustain. Cities Soc. 2019, 50, 1012-1025. [CrossRef]

36. Lyu, H.M.; Shen, S.L.; Zhou, A.N.; Yang, J. Perspectives for flood risk assessment and management for mega-city metro system. Tunn. Undergr. Space Technol. 2019, 84, 31-44. [CrossRef]

37. Zhang, N.; Shen, S.L.; Zhou, A.N.; Xu, Y.S. Investigation on performance of neural network using quadratic relative error cost function. IEEE Access 2019, 7, 106642-106652. [CrossRef]

38. Baum, R.L.; Godt, J.W. Early warning of rainfall-induced shallow landslides and debris flows in the USA. Landslides 2010, 7, 259-272. [CrossRef] 
39. Segoni, S.; Rosi, A.; Fanti, R.; Gallucci, A.; Monni, A.; Casagli, N. A regional-scale landslide warning system based on 20 years of operational experience. Water 2018, 10, 1297. [CrossRef]

40. Piciullo, L.; Calvello, M.; Cepeda, J.M. Territorial early warning systems for rainfall-induced landslides. Earth-Sci. Rev. 2018, 179, 228-247. [CrossRef]

(C) 2019 by the authors. Licensee MDPI, Basel, Switzerland. This article is an open access article distributed under the terms and conditions of the Creative Commons Attribution (CC BY) license (http://creativecommons.org/licenses/by/4.0/). 